\title{
A Greatly Exaggerated Demise: The Remaking of the Children of Paul's as the Duke of York's Men (1608)
}

The Children of Paul's acting company came to a bad end ... or did it? The current narrative, as developed by Reavley Gair in The Children of Paul's (1982), holds that the troupe made its fatal error when in 1608 it staged the satiric comedy The Puritan, thereby bringing down upon themselves the wrath of the puritan community: 'it was ... a very serious miscalculation, a blunder that was to prove largely responsible for the theatre company's demise'. ${ }^{1}$

Staging The Puritan certainly brought down the wrath of puritan divine William Crashaw. Taking specific exception to The Puritan for its lampoon of those faithful such as lived in the nearby parishes of St Antlings and St Mary Overys, on 14 February 1608 Crashaw fulminated against the Children of Paul's in a sermon delivered from the outdoor pulpit Paul's Cross, just a stone's throw away from Paul's playhouse: ${ }^{2}$

[The Children of Paul's] be children of Babylon that will not bee healed: nay, they grow worse and worse, for now they bring religion and holy things vpon the stage: no maruel though the worthiest and mightiest men escape not, when God himselfe is so abused. Two hypocrites must be brought foorth; and how shall they be described but by these names, Nicolas S. Antlings, Simon S. Maryoueries?

Are they thus incurable? then happie hee that puts to his hand to pull downe this tower of Babel, this daughter of confusion, happie he that helpes to heale this wound in our State: but most happie that Magistrate, who, like zealous Phinehes, takes some iust vengeance on that publike dishonour laid vpon our Churches. But if we be negligent in this cause of God, then hee himselfe will take the matter into his owne hand, whose Church, whose religion, whose holy ordinances and most holie name are daily prophaned by them: for as their iniquities are hainous, and their blasphemies against heauen; so doubtlesse their iudgement is gone vp vnto heauen and lifted vp vnto the cloudes. (sig Y2r-v) 
The Children of Paul's disappeared from the record subsequent to Crashaw's jeremiad and Paul's playhouse itself was closed for business by early 1609, if not sooner. ${ }^{3}$ Gair not unreasonably infers a cause-and-effect relationship between puritan anger and the disappearance of the company: Paul's playhouse 'fell as the first victim of the new Puritanism, which demanded the expulsion of plays from sacred precincts'. ${ }^{4}$

The evidence, however, contradicts itself. The 1610 legal document concerning the closure of Paul's playhouse also discloses that in the interest of preserving a monopoly on children's performances for the Children of the Queen's Revels (the Children of Paul's surviving competitor) the managers of the Queen's Revels company arranged to pay the owner of Paul's playhouse a dead-rent of twenty pounds per annum to keep the playhouse closed as of $1609 . .^{5}$ Why would any theatre company pay the owner of Paul's playhouse the handsome sum of twenty pounds annually to stay shut if the playhouse had already been closed for good by an outraged citizenry? To the contrary, the arrangement would seem to demonstrate that Paul's playhouse remained exceedingly viable - indeed, all too viable as far as the Children of the Queen's Revels were concerned. Contrary to the generally accepted narrative, I claim that the Children of Paul's troupe vacated their traditional venue for the simple reason that the core ensemble had grown too old to be plausible, or even allowable, any longer as 'children' - that, far from collapsing into failure and oblivion, they restructured themselves and flourished as an adult acting company, reappearing in October 1608 as the Duke of York's Men under the royal patronage of Prince Charles, Duke of York.

Scholars have generally assumed that the children's companies, having evolved from schools for boy choristers, were comprised entirely of children, ie, pre-adolescent boys, the children leaving the companies after their voices broke. ${ }^{6}$ Gair proposes quite a different arrangement, that ' $[\mathrm{t}]$ he name Children of Paul's was ... something of a conventional title for an acting company consisting largely of young adults, accompanied by younger boy sopranos', a proposal which the present study confirms. ${ }^{7}$ Further, young men not only made up the core acting ensemble of the Children of Paul's, but also made up the core acting ensemble of virtually every professional 'children's' company of the period.

\section{The Remaking of the Children of Paul's}

If the Children of Paul's remade themselves into an adult company, they could only have become the Duke of York's Men, since the Duke of York's Men was 
the only adult company to be constituted any time soon after the Children of Paul's disappeared from the records in February 1608. ${ }^{8}$ The next closest contender would have been the Lady Elizabeth's Men, which did not incorporate until 1611.?

The Duke of York's Men first appear in the provinces on 20 October 1608 at Ipswich. Its members are identified in a later patent, issued 30 March 1610, as John Garland, William Rowley, Thomas Hobbes, Robert Dawes, Joseph Taylor, John Newton, and Gilbert Reason. Apart from John Garland, an old stager originally part of the 1583 Queen's Men, the rest of the troupe's prior acting experience is completely unknown. The elderly Garland presumably acted as their manager and payee. He disappears from theatre records after 1612 and from there on the younger performers are on their own.

For an acting company seemingly appearing from out of nowhere, the Duke of York's Men was a remarkably talented ensemble. Joseph Taylor was eventually regarded as the greatest actor of his generation, Taylor being tapped by the King's Men within weeks to replace Richard Burbage following his death in 1619. William Rowley had a distinguished career as a stage comedian and dramatist; he is most remembered today for his co-authorship with Thomas Middleton of The Changeling. Rowley, Hobbes, Newton, and Reason had long careers with the Duke of York's Men, known later as Prince Charles' Men following the untimely death of the heir apparent Henry in 1612. Rowley and Hobbes eventually joined Taylor as members of the King's Men. Only Robert Dawes passed into an early obscurity, last being seen with the Lady Elizabeth's Men in 1614. Starting in 1610, the Duke of York's Men - soon to be Prince Charles' Men - performed frequently at Court, with Rowley writing plays for them and acting as manager and payee - a remarkable achievement for an ensemble of players with no known acting history prior to $1608 .{ }^{10}$

In contrast to the Duke of York's Men ensemble, all of whose names are known, the names of the Children of Paul's ensemble are seemingly lost to history, an unsurprising outcome since child players did not sign documents, negotiate contracts or receive payments. All that was handled by their managers. Indeed, Ben Jonson seems to have been the only one to regularly dignify the child players with individual recognition by name. He wrote Cynthia's Revels (1600), Poetaster (1601), and Epicoene (1609) for the Children of the Chapel (later known as the Children of the Queen's Revels) and he alone duly published actors' lists of the child players who performed in these productions. Thus, the 'principall Comødians' to perform in Cynthia's Revels are known to have been Nathan Field, Salomon Pavy, Thomas Day, John 
Underwood, Robert Baxter, and John Frost. ${ }^{11}$ Nor did Jonson confine himself to actors' lists. To give two examples, in the Induction to Cynthia's Revels the Third Boy is addressed as 'Sall', identifying him as Salomon Pavy ${ }^{12}$ - and when a new character, Cos, is introduced as 'A page of good timber!' (1.5.4), it is reasonable to surmise that John Underwood played the part. That is to say, Jonson seems to have salted his plays with in-joke allusions to the players' names.

Other dramatists probably did the same. If the Duke of York's Men were previously the Children of Paul's, the twenty surviving plays known to have been performed by the Children of Paul's may well contain in-joke allusions to the players' names. ${ }^{13}$ Jests and witticisms acquire extra point if a word plays upon an actor's name. For example, to return to the Cynthia's Revels example above, when Amorphus salutes Cos as 'A page of good timber!', the line is manifestly designed to raise a laugh, though it would be difficult to see what the point might be unless the player's name happens to be Underwood. The Children of Paul's repertoire may therefore contain not just a single allusion but perhaps an entire set of allusions to the members of the later Duke of York's Men; ie, Rowley, Hobbes, Dawes, Taylor, Newton, and Reason. ${ }^{14}$ The present analysis will test this.

Some context may prove useful here: In 1561 the venerable St. Paul's Cathedral suffered severe damage from fire after its steeple was struck by lightning. Its restoration was never fully completed and from then on the cathedral functioned without much maintenance at all. Its dilapidation progressed so far that by the 1650 s it was in utter ruins, to be eventually replaced by Christopher Wren's masterpiece, the St. Paul's Cathedral of today. ${ }^{15}$ By long tradition, plots of ground in Paul's Churchyard were leased out and by the 1590s the yard had become a warren of shops, sheds, and tenements mingled with a few more substantial structures. Since the church and its yard lay outside the legal jurisdiction of the City of London, the premises were rife with prostitutes, cutpurses, and other criminals as well as debtors. In The Guls Horne-booke (1609), Thomas Dekker advises the gull hard pressed by creditors that 'your Powles walke is your onely refuge'. ${ }^{16}$ Ironically, as documented in The Visitation Report of Bishop Bancroft, 1598, conditions within the cathedral itself were, if possible, even worse than outside in the yard. ${ }^{17}$ The veritably Hogarthian details described by Richard Bancroft were current throughout the tenure of the Children of Paul's.

Bancroft's official indictment charged that St. Paul's Cathedral was 'kept verie ill for Comonlie it is never $\mathrm{w}^{\text {th }}$ out a muckhill in it ... a doinghill of the quantitie of iiij or $\mathrm{v}$ loades'. ${ }^{18}$ The main aisles of the church operated 
continually as a public 'throughfare of all kynd of burden bearing people as Colliers $\mathrm{w}^{\text {th }}$ sackes of Coles Porters $\mathrm{w}^{\text {th }}$ basketts of flesh', even during church services. ${ }^{19}$ According to The Guls Horne-booke, the aisles were also a thoroughfare for tourists:

The first time that you venture into Powles, passe through the body of the Church like a Porter, yet ... not ... before you haue paid tribute to the top of Powles steeple with a single penny: And when you are mounted there, take heede how you looke downe into the yard; for the railes are as rotten as your great Grand-father.

(sig D3r)

Returning to Bancroft's Visitation Report: The stench was dreadful, a 'verie ill savour greatlie preiudiciall to mens health'; the 'savour' was not helped by the fact that 'drunkards [do] lie and sleepe upon the formes and aboute the quier dores, and other Idle and masterlesse people, where they doe verie often tymes leave all that is $\mathrm{w}^{\text {th }}$ in them verye loathsome to behould'. Alcohol figured as part of the trade, with the Butler of the College of the Minor Canons running a pub on the premises, 'suffering Captaines, Gamlers, and stranigers to drinke both bere and ale and tobacco in the petticannons haule in service tyme, and sermon tyme', with the consequence that 'by meanes of such resorte there is such fullsomenes as pissinge and other inormities that $\mathrm{y}^{\mathrm{e}}$ passages in and out to the College is both lothsome and verie unholsome'. Emulating their elders, there were 'boies ... pissinge upon stones in the Church ... to slide upon as uppon ysse'. The choir loft was liable to be invaded by 'lunatike persons and diseased persons, and Children, leaping and playinge'. ${ }^{20}$ Many of the windows were broken and the paving stones were dangerously uneven. ${ }^{21}$

Indeed, St. Paul's Cathedral was more a house of commerce than a house of worship. The cathedral itself contained an ample number of shops, few having anything to do with religion and some pursuing business even on Sundays and during services. The main aisles functioned as a social promenade, a hiring pool for servants, and a popular point of rendezvous for every conceivable kind of business. In The Black Booke (1604), Thomas Middleton summarizes this aspect of the cathedral's 'savour': 22

I walkte in Powles to see fashions; to diue into villainous meetings, pernitious Plots, blacke Humours, and a Million of mischiefes, which are bred in that Cathedrall Wombe, and borne within lesse then forty weekes after. But some may obiect and say; What doth the Diuell walke in Powles then? Why not, Sir, aswell as a Seriant, or a Ruffian, or a Murtherer: may not the Diuell I pray you walke in Powles as well.

(sig D4v-E1r) 
In short, the puritans were more out of place at Paul's than the players. William Crashaw's sermon could hardly have inspired a positive response from the Paul's regulars. The Children of Paul's company was an important draw for customers, customers who likely would spend more of their money elsewhere within the precincts. With respect to sanctimonious critics, the players had the upper hand. Not only did the Children of Paul's perform on Sundays, but, according to Crashaw, sermons were even occasionally curtailed so as not to infringe upon the players' starting time: ${ }^{23}$

Oh what times are wee cast into, that such a wickednesse should passe vnpunished! I speake nothing of their continuall prophanenesse in their phrases, and sometime Atheisme and bla[s] phemie, nor of their continuall prophaning of the Sabbath, which generally in the countrie is their play day, and oftentimes Gods diuine seruice hindred, or cut shorter to make roome and give time for the diuels seruice.

(sig $\mathrm{Y} 2 \mathrm{r}-\mathrm{v})$

The conditions at Paul's well explain how the Children of Paul's acting troupe could stage such a cheekily irreverent comedy as The Puritan and expect to get away with it. Twenty plays are known to have been performed by the Children of Paul's. Of these, fourteen contain no possible references to members of the later Duke of York's Men - Rowley, Hobbes, Dawes, Taylor, Newton, and Reason - but six do. These potentially slippery allusions will benefit from a closer interrogation.

To begin: In Middleton's Michaelmas Term (written c 1604) a Tailor appears briefly in the third act to converse with a Country Wench: ${ }^{24}$

Wench: Why doe you worke a sundaies Taylor?

Taylor: Hardest of al a Sundaies, because we are most forbidden. (3.1.11-13)

This interchange marks the apparently irrelevant bantering between them. The anonymous tailor leaves at the end of the scene - a small part easily doubled with one of the larger roles. This by-play is almost certainly an in-joke referencing the Children of Paul's damnable Sunday performances as well as making a gesture toward the young Joseph Taylor. Likewise, in the opening scene of Dekker and Webster's Westward Ho (written c 1604) another anonymous tailor appears, only to be verbally abused by Mistress Birdlime: ${ }^{25}$ 'Taylor, you talk like an asse' (1.1.24). Again, the part is small and easily doubled with one of the major roles. The line fits with the action onstage, but the verbal gibe has more edge if the Tailor were played by Joseph Taylor, the Children of 
Paul's rising star. Later in the same play, Master Honeysuckle, lately arrived in England, asks Justiniano the news:

Honeysuckle: [W] hat newes flutters abroad? doe Iack-dawes dung the top of Paules Steeple still[?]

Justiniano: The more is the pitty, if any dawes do come into the temple, as I feare they do.

Is this defiler of Paul's a feathered allusion to another 'defiler' of the temple, the player Robert Dawes?

In John Marston's Antonio and Mellida (written c 1599), some overly suggestive by-play occurs between Flavia and the page Dildo: ${ }^{26}$

Flavia: Nay, faith, there's reason in all things.

Dildo: Would I were reason, then, that I might be in all things.

Assume, for the moment, that the scandalous Dildo was played by Gilbert Reason. Another allusion to Reason, in a line adapted from Shakespeare, occurs in the anonymous play The Wisdom of Doctor Dodypoll (written c 1600). In Shakespeare's Julius Caesar (1599), Mark Antony brings his 'Friends, Romans, countrymen' speech to its resounding climax: ${ }^{27}$ 'O judgment, thou art fled to brutish beasts, / And men have lost their reason!' (3.2.101-2) In Doctor Dodypoll the Doctor and Alphonso attempt to seize Alberdure, the temporarily insane son of Alphonso: ${ }^{28}$

Alphonso: Lay holde vpon him, helpe the Doctor there[!]

Alberdure: Then reason's fled to animals I see,

And Ile vanish like Tobaccho smoake. Exit. (1l. 906-8)

After a pun this bad, Reason has every need to make a quick exit.

I have reserved the most complex set of allusions for last, the popular use of the catch-phrase rowly powly, also spelled rowle powle (a phrase unrelated to the later roly poly, which did not appear until the eighteenth century [OED]). Rowly powly's earliest datable appearance is in Jonson's Poetaster (1601), written for the Children of the Chapel some two years after the revival of the Children of Paul's in 1599. ${ }^{29}$ Rowly powly appears four times in plays written for the children's troupes and only twice anywhere else in the literature of the time (in Jonson's A Tale of a Tub, written for an unknown acting troupe, and in Samuel Rowlands' poem Hell's Broke Loose). ${ }^{30}$ The catchphrase rowly powly seems, in fact, to have originated in the world of the 
children's acting troupes, its use extending only very slightly beyond their domain. The OED defines rowly powly as 'a worthless fellow; a rascal' but provides no etymology. I propose here that its etymology derives from the eponymous William Rowley of Paul's playhouse (also spelled Powles).

In Poetaster, set in Augustan Rome, Ovid's slave Luscus imprudently interjects his opinion into an argument taking place between Ovid and his father. Tucca, a guest, turns upon the unhappy Luscus: ${ }^{31}$

Tucca: [to Luscus] How now, good man slaue? what, rowle powle? all riualls, rascall?

[to Ovid senior] why my master of worship, do'st heare? Are these thy best proiects? is this thy desseignes and thy discipline, to suffer knaues to bee competitors with commanders and gent'men? [to Luscus] are wee paralells, rascall? are wee paralells?

Ovid's father promptly orders Luscus out to take care of the horses. In Jonson's $A$ Tale of a Tub a similar interchange takes place. ${ }^{32}$ Hilts is looking for the High Constable and declines to speak with the High Constable's henchman Ball Puppy as beneath his dignity, dismissing him as a 'young Clowne' and a 'Jade' (2.2.4-7). Puppy vehemently objects to such treatment, to which Hilts retorts, 'What? Rowle-powle? Maple-face? All fellowes?'(2.2.15). ${ }^{33}$ Luscus and Puppy are both clowns being rebuked by their superiors for acting above their station (or, alternatively, for seeking to drag their superiors down to their own level, which comes to much the same thing). The same dynamic occurs in Robert Armin's play The Two Maids of More-Clacke (published 1609) when a man rebukes his servant for speaking in too familiar a manner to him, saying, 'Saucebox, rowly powly, am I not your master?' (scene 16.7).34

Rowly powly is applied politically and historically in Samuel Rowlands' poem Hell's Broke Loose (1605), a verse monologue written in the voice of the late Anabaptist revolutionary John of Leiden, who, with his fellow commoners, seized the city of Münster in 1534 to establish a short-lived would-be utopia. It all comes to a bad end and Rowlands is glad that it did. In his address 'To the Reader', Rowlands describes these commoner revolutionaries as 'Boores' and 'vulgar illiterate Clownes' (sig. A1v). ${ }^{35}$ In the verse monologue Rowlands has John of Leiden say,

Why, Kings are made of Clay; and so are wee:

Wee'le ayme our thoughts on high, at Honors marke:

All rowly, powly; Tayler, Smyth, and Clarke.

(sig. B3 ${ }^{\mathrm{r}}$ 
From Rowlands' point of view, these historical figures are upstarts with aspirations very much above their station.

These examples of rowly powly all suggest a more pointed meaning than simply 'rascal' or 'worthless fellow', as the $O E D$ would have it. A rowly powly is more specifically a presumptuous buffoon, a clown with delusions of grandeur, one who does not know his place. The two instances of rowly powly in the Children of Paul's repertory serve to reinforce this point. First, in Dekker's Blurt, Master Constable (written c 1602), Lazarillo, a miles gloriosus, seeks to impose upon Blurt the constable with his papers: ${ }^{36}$

Lazarillo: I have the Generals hand to passe through the world at my pleasure.

Blurt: $\quad$ At your pleasure? thats rare; then rowlie, powlie, our wives shall lye at your commaund: your Generall has no such authoritie in my Presincte, and therefore I charge you passe no further.

Constable Blurt has quickly sized up Lazarillo as a presumptuous buffoon, a rowly powly.

The other instance of rowly powly appears in Dekker's Satiromastix. To provide some background, in addition to having Tucca abuse Luscus, Jonson went to lengths in Poetaster (1601) to lampoon John Marston and Thomas Dekker in the characters of Crispinus and Demetrius respectively, a pair of talentless would-be poets seeking to crash the poet scene. Personating himself as the great Latin poet Horace, Jonson administers to these two hacks what he regards as a well-deserved comeuppance (5.3.213-565). ${ }^{37}$ In Satiromastix (1601) Dekker pays tit for tat. Horace, Crispinus, Demetrius and even Tucca once again take to the stage, but now it is Horace/Jonson's turn to be put in his place. Tucca this time acts as a mock-mediator between Horace and the other two: ${ }^{38}$

Tucca: Ile haue thee [Horace] in league ... with these two rowly powlies: they shal be thy Damons and thou their Pithyasse; Crispinus shall giue thee an olde cast Sattin suite, and Demetrius shall write thee a Scene or two, in one of thy strong garlicke Comedies; and thou shalt take the guilt of conscience for't, and sweare tis thine owne olde lad, tis thine owne.

Here, Demetrius/Dekker has Tucca claim that Horace/Jonson has been giving himself too many airs: His wardrobe is meager and as for the supposedly worthless Demetrius/Dekker, he has penned 'a Scene or two' for Jonson's plays 
which the great poet has not seen fit to properly acknowledge. Thus, Marston and Dekker will concede to Jonson that they are indeed 'rowly powlies', presumptuous buffoons, provided that Jonson concedes that he is one, too that they are all fellows in folly, two Damons to his 'Pithyasse'. The historical Horace did not, of course, write plays; Dekker is addressing Jonson the dramatist directly.

These instances comprise every known use of rowly powly in the literature of the time. Among possible links between William Rowley, stage clown and dramatist for the Duke of York's Men, and the earlier Children of 'Powles', the theatrical catch-phrase rowly powly stands out. If William Rowley began his stage career with the Children of Paul's in 1599-1600, prior to the first appearances of rowly powly as a familiar catch-phrase in Poetaster and Satiromastix in 1601, the young player may well have been referred to in theatrical circles as 'Rowley of Powles' to distinguish him from Samuel Rowley, already well established as a player and dramatist with the Admiral's Men. ${ }^{39}$ By way of William's roles as a clown, 'Rowley of Powles' would then easily have become the stage name Rowly Powly, just as Pickleherring was the stage name of another popular clown, Robert Reynolds. ${ }^{40}$ The evidence indicates that William Rowley was a gifted comedian with a bent for portraying upstart clowns. Of eight identified roles, ${ }^{41}$ all but one are variations upon the presumptuous buffoon. ${ }^{42}$ From there it would have been but a small step for the nickname Rowly Powly to become generalized to signify any presumptuous buffoon, on or off the stage.

Seven passages, then, from the Children of Paul's repertoire contain possible allusions to Rowley (2), Taylor (2), Reason (2), and Dawes (1). While there are no discernible allusions to Thomas Hobbes or John Newton (the other two players with the Duke of York's Men), neither one had a last name that lent itself readily to wordplay. Now, any one of these seven allusions may have presented itself by simple coincidence, a seeming wordplay resulting in a pseudo-allusion - and if this can hold true for any one of these allusions, why not all seven? Or, put another way, given six names, how many pseudoallusions might be expected to occur in a collection of twenty plays?

To conveniently answer this question, take the names of the six Children of the Chapel players as recorded by Jonson in 1601 - Nathan Field, Salomon Pavy, Thomas Day, John Underwood, Robert Baxter, and John Frost - and look for allusions to their last names in the twenty plays belonging to the Children of Paul's repertoire (see note 13). Since there should be no allusions whatever to members of the Children of the Chapel in a Children of Paul's play, any 'allusions' found are necessarily pseudo-allusions. 
These twenty plays yield a single pseudo-allusion: In Middleton's A Trick to Catch the Old One (published 1608) an abusive alcoholic usurer named Dampit goads his callers with his ranting until he finally falls into a drunken stupor: ${ }^{43}$

Gulfe: A litle thing would make me beat him, now he's asleep.

Lancelot: Masse then twilbe a pittifull day when he wakes. I would loath to see that day, come.

This might be an allusion to Thomas Day playing the drunken Dampit, but it is not: Day was not a member of the Children of Paul's. It is a pseudo-allusion. The words field, day, and frost occur frequently enough in these twenty plays, but none of the other instances suggests even the possibility of a pseudo-allusion. Pseudo-allusions do occur, then, but only rarely. For a set of six names unconnected with the Children of Paul's, only one pseudo-allusion shows up in twenty plays. Thus, while one or another of the seven allusions to members of the later Duke of York's Men may indeed be a pseudo-allusion, it is exceedingly unlikely that all seven are.

With these findings in hand, a high degree of certainty supports the view that the Children of Paul's company - seen for the last time in February 1608 - vacated Paul's playhouse to restructure themselves as the Duke of York's Men, seen for the first time in October 1608. Eight months will not transform children into men, so it follows that the 'Children' of Paul's were actually an ensemble of young men, at least toward the end of their tenure at Paul's. To assess whether this was an exceptional arrangement or the norm requires a review of the organization of the children's companies in early modern England.

\section{The Organization of the Children's Companies}

The two major Elizabethan children's troupes, the Children of Paul's and the Children of the Chapel, had their origin in two schools for boy choristers maintained at St. Paul's Cathedral and the Chapel Royal respectively. ${ }^{44}$ The boy singers were traditionally provided an education with room and board until their voices broke; thereafter the best of them went on to pursue careers in music, composing and adult singing. ${ }^{45}$ Prior to Elizabeth's reign the performance of plays, before the court and other privileged audiences, was only occasional and incidental to a pedagogy which saw amateur acting as a useful element within a more general curriculum. ${ }^{46}$ 
By the 1570 s the choirmasters had realized that their charges would put on more polished play productions before the court if they rehearsed on a regular basis before a live audience. Soon the children's acting companies were performing regularly in permanent playhouses before paying spectators. By 1575 Sebastian Westcott, master of the Children of Paul's, was the target of a complaint to the Court of Aldermen because he 'kepethe playes and resorte of the people to great gaine and peryll of the Corruptinge of the Chyldren with papistrie' - a shot at Westcott's Catholicism, among other things. ${ }^{47}$ In 1576 Richard Ferrant, master of the Children of the Chapel, leased space in Blackfriars, space that he remodeled into a theatre against the wishes of the owner, Sir William More: 'fferrant pretended vnto me to vse the howse onlie for the teachinge of the Children of the Chapell but made it a Continuall howse for plays to the offence of the precincte $\&$ pulled downe particons to make that place apte for that purpose'. ${ }^{48}$ These accusations had no discernible effect. Westcott and Ferrant prospered. ${ }^{49}$

What began as the occasional amateur performance now became a commercial enterprise in its own right. Throughout, the fiction was maintained that performances by the children's troupes were 'private' and therefore amateur, but this could hardly have fooled anyone. Indeed, in 1578 the Privy Council duly listed the Children of Paul's and the Children of the Chapel alongside four professional adult companies as constituting the six companies licensed 'to exercise playes within the Cittie'. ${ }^{50}$ Thus, by that date the two children's troupes were already recognized as de facto professional acting companies, if not de jure.

If the 'amateur' status of the child players was a polite fiction, was their status as 'children' likewise a fiction? Schools for choristers regularly provided further opportunities for their more gifted students after their voices broke, so it should come as no surprise if the same held true for the children's acting companies. The process may be demonstrated by the career of Nathan Field, player and dramatist. Born in 1587, Field was recruited to the Children of the Chapel (later the Children of the Queen's Revels) when he was twelve or thirteen and he continued with them until they finally combined with the Lady Elizabeth's Men in 1613, at which point Field was in his twenties. ${ }^{51}$ After the merger there were seven players performing with the Lady Elizabeth's Men who were previously actors with the Children of the Queen's Revels. Indeed, they seem to have largely taken over the Lady Elizabeth's Men. ${ }^{52}$ As would have been true with the remaking of the Children of Paul's as the Duke of York's Men, the 'Children' of the Queen's Revels did not 
become men overnight. In both cases the core ensemble surely had consisted of young men for some time.

Young men appear to have been integral to the children's companies for many years. Over the decades, the number of choristers officially on the roster of the Children of Paul's varied only slightly between nine and eleven. Yet for its performance of Scipio Africanus in 1580 and again for its performance of Pompey in 1581 the company was issued eighteen pairs of gloves by the Revels Office, which implies there were eighteen recognized members of the company. ${ }^{53}$ The discrepancy in numbers can be resolved by examining Sebastian Westcott's will of 1582. Among numerous detailed bequests, the late Master of the Children of Paul's left generous sums to eight or nine ex-choristers still living on the premises of Paul's Cathedral. For five of these ex-choristers whose ages can be estimated, four were around twenty years old and one was close to forty. ${ }^{54}$ Lennam suggests that the ex-choristers were 'useful to [Westcott's] theatrical enterprise, perhaps aiding, and some of them even augmenting, the ten choristers in the more spectacular and demanding presentations of classical legend and history'. ${ }^{55}$ But Lennam may have put the cart before the horse. The evidence suggests with even greater force that the adult ex-choristers were the core ensemble of the acting wing of the Children of Paul's under Westcott, with the official choristers serving as the extras.

Years later, when Christopher Beeston came to organize the Beeston's Boys troupe (also known as the King and Queen's Young Company) in 1637, he had a core ensemble of seven adult players from the very start. ${ }^{56}$ G.E. Bentley puzzled over this arrangement. Committed as he was to the idea that a children's company should be comprised of children (what else made sense?), he finally allowed the evidence to persuade him: ${ }^{57}$

All these facts lead to the following conclusions: (1) The company of Beeston's Boys was so called not because it was made up entirely of children, but because it made use of an unusually large number of boys (which would account, among other things, for the surprising number of solos and choruses in The Jovial Crew, which Richard Brome wrote for the company). (2) The company included several adults, probably enough for most of the adult roles in their plays. ${ }^{58}$

Beeston could hardly have been an innovator in this regard. Beeston himself had been a cast member in Jonson's Every Man in His Humour (1598) and was an active performer in the London theatre scene throughout the tenure of the revived children's companies. ${ }^{59}$ When he came to organize the King and 
Queen's Young Company in 1637 there was no need for him to improvise; he knew from direct personal knowledge how the children's troupes had been organized in his younger days. Indeed, when the Children of the King's Revels incorporated in 1607-8, the Articles of Agreement described the older performers in the new children's company as 'younge men and ladds'. ${ }^{60}$

Given the misunderstandings which could arise when a 'children's' troupe was largely made up of young men and adults, it is reasonable to suppose that - as with any other specialized profession - a nomenclature would have developed to keep clear the distinctions. Shen Lin, in 'How Old were the Children of Paul's?', concluded that no such jargon developed and that all references in the records to 'children' and 'youths' in relation to the children's companies were inherently ambiguous. ${ }^{61}$ However, an unusual document not previously brought to bear on the matter may serve to shed some light.

The rarely noted Children of Bristol incorporated under the patronage of Queen Anne in 1615, its patent stipulating that those responsible were to form the company from 'children and youthes'. ${ }^{62}$ In June 1618 Ignatius Jurdain, mayor of Exeter, wrote a letter of complaint concerning the Children of Bristol, the letter being sent to Sir Thomas Lake, principal secretary to His Majesty:

May it please you to be aduertised that 6 dayes past thear cam to our Cittie certaine players who cam vnto me desiring leave to playe whearvpon I pervsed their patent and finding that it is only for children and youthes (for so ar the wordes) I did with aduise of som of the aldermen of this cittie restraine them from playing hear, for that thear being fivetene of thear company thear ar but only five youthes among them, and all the rest ar men som about 30 and 40 and 50 yeares as they hav confessed vnto me, as also of their age, vpon which cause I prayed them to dissist and gave them fower Angells toward their expence, which seemed to me they wear content. ${ }^{63}$

But they were not content. The Children of Bristol intended to submit a complaint to the Privy Council and Jurdain's own complaint had been sent in an effort to anticipate theirs.

The mayor's complaint is direct and specific: as there are no children among the 'Children' of Bristol, there will be no performances. That there are 'five youthes' in the company is not enough. The mayor expects that the distinction he is making between children and youths, with respect to the Children of Bristol, will be clear and unambiguous to his majesty's secretary, to the Privy Council, and to the players themselves. So confident is he, in fact, that he is attaching a copy of the Children of Bristol's patent to his 
complaint to make his point. The mayor's complaint assumes a clear and meaningful distinction between children and youths with respect to professional acting companies and his argument turns upon the incontestable fact that there are no children in the Children of Bristol. The players' counter-argument - it has not survived - would presumably have been that the absence of children among the players was irrelevant, a mere quibble, given that it was common knowledge that professional 'children's' troupes were routinely made up of youths and men, something the Privy Council in London was in a position to know.

This contretemps indicates that a generally understood nomenclature did exist to distinguish among children, youths and men in the playing profession. For the players' purposes, a youth would differ from a child on the basis of sexual maturity, the line of demarcation being crossed when the child's voice broke. Today the voice breaks, on the average, when a boy reaches thirteen years of age, but in the early modern period the average voice broke at about age fifteen or sixteen, as noted by choirmasters. ${ }^{64}$ The difference between then and now can be attributed primarily to differences in nutrition.

Unlike a breaking voice serving to distinguish children from youths, the line of demarcation between youths and men was necessarily somewhat arbitrary, being determined by cultural practice more than biology. Current culture frequently posits age eighteen as the age when an adolescent boy is to be officially considered a man. Rather surprisingly, in early modern England a youth was generally not considered to have reached manhood until he was twenty-four years old. ${ }^{65}$ Prior to that, the authorities saw him as a youth, others referred to him as a youth, and he quite naturally regarded himself as a youth. Therefore, it was entirely reasonable and socially acceptable for a twenty-three-year-old player to perform as part of a 'children's' troupe. A twenty-four-year-old player was quite another matter: He was now a man and should act like a man. It is for this reason that the mayor of Exeter emphasizes in his complaint that the older players of the Children of Bristol are ' 30 and 40 and 50 yeares as they hav confessed vnto me'; they are most emphatically not under twenty-four years of age. Shakespeare himself alludes to this age distinction when the Old Shepherd in The Winter's Tale bemoans that there even is such a thing as 'youths': 'I would there were no age between ten and three-and-twenty, or that youth would sleep out the rest; for there is nothing in the between but getting wenches with child, wronging the ancientry, stealing, fighting' (3.3.58-61).

The actions of Nathan Field indicate that London players took the twenty-three-year-old age limit very seriously. Baptized 17 October 1587, 
Field registered his play $A$ Woman is a Weather-cocke for publication on 23 November 1611, some five weeks after he turned twenty-four. In his epistle 'To the Reader', Field bids adieu both to his fans and to his career with the Children of the Queen's Revels, 'Fare thee well, if thou hast any thing to say to me, thou know'st where to heare of me for a yeare or two, and no more I assure thee.' 66 To paraphrase, Field has ceased acting with the Children of the Queen's Revels as of his twenty-fourth birthday. He will resume his acting career after he has joined an adult company, which may take a year or two. In the meantime, anyone wishing to contact him can do so by way of the Children of the Queen's Revels. However, the Queen's Revels' willingness to forward messages must not be construed as Field maintaining an inappropriate relationship with a children's company now that he is an adult. Once Field has established himself with an adult company, all further communication will be through them, 'I assure thee'. As it was, by March 1613 negotiations were underway to fold the 'Children' of the Queen's Revels into the Lady Elizabeth's Men - with Field himself coming out on top as the payee and representative of the new Lady Elizabeth's Men. ${ }^{67}$ Unwilling to part with his fellow troupers, it would appear that Field took them with him.

The distinction made between children and youths serves to clarify an account given of the Children of Paul's performance on 30 July 1606 before James and the visiting King Christian IV of Denmark: ${ }^{68}$

On Wednesday at night, the Youthes of Paules, commonlye cald the Children of Paules, plaide before the two Kings, a playe called Abuses: containing both a Comedie and a Tragedie, at which the Kinges seemed to take delight and be much pleased.

$\left(\right.$ sig $\left.\mathrm{C}^{v}\right)$

Here the distinction is insisted upon that the players are 'Youthes', that is to say, young men, not children.

It appears the Children of Paul's players were young men practically from the start. Following a hiatus of ten years, the Children of Paul's was revived in 1599, but already by 1602 the Paul's players were being referred to as 'youths'. In Middleton's play The Family of Love (written c 1602 for the Children of Paul's), Glister and Dryfat meet Gerardine, Lipsalve and Gudgeon on the street: ${ }^{69}$

Glister: And from what good exercise come you three?

Gerardine: From a play, where we saw most excellent Sampson excel the whole world in gate-carrying.

Dryfat: Was it performed by the youths? 
Lipsalve: By youths? Why, I tell thee we saw Sampson, and I hope 'tis not for youths to play Sampson. Believe it, we saw Sampson bear the town-gates on his neck from the lower to the upper stage, with that life and admirable accord that it shall never be equaled.

Lipsalve denies that youths are capable of such an exceedingly burly role as Samson. However, he and Dryfat are talking at cross-purposes. Lipsalve is speaking of Samson the character, whereas Dryfat is referring to 'it'; ie, Samson the play. Samson, a new play, was in performance by the Admiral's Men at the Fortune in the latter half of 1602 (the text has not survived) ${ }^{70}$ Except for the part of Samson, nobody is disputing that the youths of Paul's can handle the other adult roles in the Admiral's Men's play.

When in 1608 the Children of Paul's finally vacated Paul's Playhouse to remake themselves as the Duke of York's Men, it seems a reasonable assumption that the older members of the ensemble were approaching the witching year of twenty-four after which it would no longer be dignified or socially appropriate for them to continue in, or as, a 'children's' troupe.

\section{Conclusions}

In his 1982 book The Children of Paul's Gair concluded, contrary to the prior consensus, that ' $t$ ] he name Children of Paul's was ... something of a conventional title for an acting company consisting largely of young adults, accompanied by younger boy sopranos'. ${ }^{71}$ The present essay confirms Gair's conclusion and extends it to other children's troupes of the period. Once a children's company had matured into a viable commercial enterprise - most likely in a year or two - its normal and ordinary form was that of a stable ensemble of young adult players backed up by a team of boy choristers who came on for song and dance numbers and to swell crowd scenes.

Directors today routinely cast important teenage roles using actors who are in their twenties. Not only are such actors more professional than actual teenagers in their contracts, negotiations, and work habits, but, paradoxically, they routinely bring an authority and presence to their roles as 'teenagers' which actual teenage actors can only occasionally achieve. Examples can be multiplied indefinitely: Actor Michael J. Fox was twenty-four to twenty-nine years old when he was portraying the harassed teenager Marty McFly in the movie triology Back to the Future (1985-90). ${ }^{72}$ More recently, actor Tobey Maguire portrayed the teenager Peter Parker in the movie Spider-Man (2002) 
when he was twenty-seven years old; by the time Spider-Man 3 comes out (scheduled for release in 2007) he will be thirty-two years old. ${ }^{73}$ And if a TV producer can put together a winning ensemble of actors in 'teenage' roles, that ensemble will be kept together as 'teenagers' until the last dog dies.

There has been a critical conversation as to whether the child actors of early modern England were able to manage the complex adult roles written for them by Marston, Chapman, Jonson, Shakespeare, and others. ${ }^{74}$ The evidence presented here suggests that the answer lies not in the capacity of children to play 'adults', but rather in the acting abilities of young men - for many, if not most, of the best 'children's company' players of that period were not children at all, but young men.

\section{Notes}

1 Reavley Gair, The Children of Paul's: The Story of a Theatre Company, 1553-1608 (Cambridge, 1982), 163.

2 William Crashaw, A Sermon Preached at the Crosse, Feb. xiij. 1607 [1608] (London, 1608), STC: 6027, sig Y2r-v.

3 Gair, 173.

4 Gair, 175.

5 Gair, 173.

6 Harold Newcomb Hillebrand, The Child Actors: A Chapter in Elizabethan Stage History (Urbana, 1926); Anthony Caputi, John Marston, Satirist (New York, 1961); Trevor Lennam, Sebastian Westcott, the Children of Paul's and The Marriage of Wit and Science (Toronto, 1975); Michael Shapiro, Children of the Revels: The Boy Companies of Shakespeare's Time and Their Plays (New York, 1977); Joy Leslie Gibson, Squeaking Cleopatras: The Elizabethan Boy Player (Stroud, 2000).

7 Gair, 155.

8 E.K. Chambers, The Elizabethan Stage 4 vols (Oxford, 1923), 2.242.

9 Chambers, 2:246.

10 Information regarding the Duke of York's Men and its individual players is excerpted from Chambers, vol 2, and from Gerald Eades Bentley, The Jacobean and Caroline Stage, 7 vols (Oxford, 1941-68), vol 2.

11 Ben Jonson, Cynthia's Revels, in C.H. Herford and Percy and Evelyn Simpson (eds), Ben Jonson, 11 vols (Oxford, 1925-63), 4:184. Hereafter the collection is abbreviated as $\mathrm{H} \& \mathrm{~S}$. 
12 Jonson, Cynthia's Revels, in H\&S, 4:42. The Third Boy is addressed as 'Sall' in the 1601 Quarto of Cynthia's Revels (1. 222n). Sall is changed to child in the 1616 Folio text.

13 After a hiatus of ten years, the Children of Paul's was revived in 1599; so the twenty plays in question are those performed by the 'Second' Children of Paul's between 1599 and 1608. The plays are as follows (the spelling and punctuation of the titles have been modernized):

\begin{tabular}{lll} 
Date & Title & Author(s) \\
\hline 1599 & Antonio and Mellida & Marston \\
1600 & Jack Drum's Entertainment & Marston \\
1600 & The Wisdom of Doctor Dodypoll & Anonymous \\
1600 & The Maid's Metamorphosis & Anonymous \\
$1600 / 1$ & Antonio's Revenge & Marston \\
1601 & Blurt, Master Constable & Dekker \\
1601 & What You Will & Marston \\
1601 & Satiromastix & Dekker \\
1601 & Love's Metamorphosis & Lyly \\
$1602 / 3$ & The Family of Love & Middleton \\
1603 & The Phoenix & Middleton \\
1604 & A Trick to Catch the Old One & Middleton \\
1604 & Bussy D'Ambois & Chapman \\
1604 & Westward Ho & Dekker and Webster \\
1605 & Northward Ho & Dekker and Webster \\
1605 & The Fawn & Marston \\
1605 & Michaelmas Term & Middleton \\
1605 & A Mad World, My Masters & Middleton \\
1606 & The Woman Hater & Beaumont and Fletcher \\
1606 & The Puritan & Middleton
\end{tabular}

Gair, 186-7, and Shapiro, Children of the Revels, 262-3, are in agreement as to the list but have some differences as to dates of performance and authors. The present study is unaffected by such differences.

14 I will be looking only for word plays upon last names, since first names are generally too non-specific for our purposes (although 'Salomon' was evidently too good a first name to pass up).

15 Gair, 13-43.

16 Thomas Dekker, The Guls Horne-booke (London, 1609), STC: 6500, sig D2r.

17 The Visitation Report of Bishop Bancroft, 1598 (Guildhall MS. 9537/9). Quotations from the Report are as given by Gair, 25-31. 
18 Gair, 25.

19 Gair, 26.

20 Gair, 26-7.

21 Gair, 31.

22 Thomas Middleton, The Blacke Booke (London, 1604), STC: 17875, sig D4v-E1r.

23 Crashaw, A Sermon Preached at the Crosse, sig Y2r-v.

24 Thomas Middleton, Michaelmas Term and A Trick to Catch the Old One: $A$ Critical Edition, George R. Price (ed) (Paris, 1976), 58.

25 Thomas Dekker, Westward Ho in Fredson Bowers (ed), The Dramatic Works of Thomas Dekker 4 vols (Cambridge, 1953-61), 2:319. Hereafter abbreviated as Bowers, Dekker.

26 John Marston, Antonio and Mellida: The First Part, G.K. Hunter (ed) (Lincoln, 1965), 24.

27 William Shakespeare, Julius Caesar in Stephen Greenblatt, Walter Cohen, Jean E. Howard, Katharine Eisaman Maus (eds), The Norton Shakespeare (New York, 1997). All Shakespeare references are to this Norton edition.

28 The Wisdom of Doctor Dodypoll, 1600, M.N. Matson (ed) (Oxford, 1965), sig E1r. This Malone Society edition is not paginated by number.

29 One instance of rowly powly is of uncertain date: Roger Armin's The Two Maids of More-Clacke cannot be assigned any specific date between 1597 and 1609. For a discussion of the dating evidence, see Roger Armin, An Old-Spelling, Critical Edition of The History of the Two Maids of More-Clacke, Alexander S. Liddie (ed) (New York, 1979), 13-24.

30 As stated on its title page, Dekker's Satiromastix (London, 1601) was performed by both the Children of Paul's and the Chamberlain's Men. See Dekker, Satiromastix in Bowers, Dekker, 1:299.

31 Jonson, Poetaster, in H\&S, 4:209-10.

32 In her essay, 'Harking Back to Elizabeth: Ben Jonson and Caroline Nostalgia', ELH 48 (1981), 706-31, esp. 725-7, Anne Barton makes an excellent case for Jonson's writing $A$ Tale of a Tub in 1633 as a calculated piece of nostalgia for the good old days of Queen Elizabeth. Given that the revival of the children's troupes (1599-1613) was long past, Jonson's use of rowly powly in Tub served as one more archaizing touch among many, in this case a popular late-Elizabethan catch-phrase now almost entirely lost to memory.

33 Jonson, The Tale of a Tub in H\&S, 3:27-8. The abusive maple-face appears to signify that Puppy has a deep tan, identifying him as a common laborer (when 
he is not henching for the High Constable) and therefore properly beneath Hilts' consideration.

34 Armin, The Two Maids of More-Clacke, 173. Armin ratchets up the comedy through the familiar dramatic device of having had master and servant trade places earlier. Thus, the 'master' who is verbally abusing his 'servant' for being a rowly powly is actually the servant taking advantage of his temporary role as 'master' to heap abuse upon his master in his temporary role as 'servant'. This servant is very much a rowly powly indeed.

35 Samuel Rowlands, The Complete Works of Samuel Rowlands, 1598-16283 vols (New York, 1966 [1880]), vol 1. This edition consists of facsimiles of the first editions. There is no through pagination by number.

36 Thomas Dekker, A Critical Old-Spelling Edition of Thomas Dekker's Blurt, Master Constable (1602), Thomas Leland Berger (ed) (Salzburg, 1979), 63.

37 Jonson, Poetaster, 4:304-15.

38 Dekker, Satiromastix, in Bowers, Dekker, 1:325.

39 Chambers, 2:337.

40 Chambers, 2:336.

41 The roles are given in Bentley, The Jacobean and Caroline Stage, 2.556: Jacques in Rowley's All's Lost By Lust; Plumporridge in Middleton's The Inner Temple Masque; the Fat Bishop in Middleton's A Game at Chess; Tony in Fletcher's $A$ Wife for a Month; Cacafogo in Fletcher's Rule a Wife and Have a Wife; Bustofa in Fletcher and Rowley's The Maid in the Mill; the Cook in Rollo, Duke of Normandy (partly by Fletcher); and the Clown in The Fair Maid of the Inn (author uncertain).

42 The exception, Tony in $A$ Wife for a Month, is a bluntly honest court fool with no personal ambitions.

43 Middleton, Michaelmas Term and A Trick to Catch the Old One, 202.

44 Shapiro, Children of the Revels, 1-29.

45 Shapiro, 234-5.

46 Shapiro, 2-3.

47 Lennam, Sebastion Westcott, 43.

48 C.W. Wallace, The Evolution of the English Drama Up to Shakespeare (Berlin, 1912), 175.

49 Shapiro, 14-15.

50 Lennam, 44.

51 Chambers, 2:316.

52 Chambers, 2:251.

53 Lennam, 39. 
54 Lennam, 38-9.

55 Lennam, 39.

56 Bentley, The Jacobean and Caroline Stage, 1.324n.

57 Bentley, 1.325n.

58 Bentley later modified his understanding of Beeston's Boys, concluding that the company functioned at least partly as a training school for young actors. See Gerald Eades Bentley, The Profession of Player in Shakespeare's Time 1590-1642 (Princeton, 1984), 142-4.

59 Chambers, 2:302.

60 Chambers, 2:66.

61 Shen Lin, 'How Old were the Children of Paul's?', Theatre Notebook 45 (1991), 121-31.

62 Chambers, 2.68.

63 John M. Wasson (ed), Devon, REED (Toronto, 1986), 188-9.

64 Gibson, Squeaking Cleopatras, 66-7.

65 Ira Clark, Comedy, Youth, Manhood in Early Modern England (London, 2003), $16-7$.

66 Nathan Field, A Woman is a Weather-cocke (London, 1612), STC: 10854, sig. $\mathrm{A} 3 \mathrm{v}$.

67 M.E. Williams, 'Nathan Field', ODNB 19 (Oxford, 2004), 481-2; Chambers, 2:316.

68 The King of Denmarkes Welcome (London, 1606), STC: 5194, 16.

69 Thomas Middleton, The Family of Love, Simon Shepherd (ed) (Nottingham, 1979), 12. The Family of Love was first published anonymously in 1608, but its allusions to the play Samson indicate it was written in 1602-3, at which time Samson was being performed by the Admiral's Men. An initial attribution of The Family of Love to Middleton has been subsequently confirmed by an analysis of the play's stylistic features. See David J. Lake, The Canon of Thomas Middleton's Plays (Cambridge, 1975), 91-108. Since Middleton was not working for the Children of the Chapel at this time, the play was written for the Children of Paul's.

70 Charles William Wallace, 'The Children of the Chapel at Blackfriars 15971603', University Studies 8 (1908), 109n1.

71 Gair, 155.

72 'Michael J. Fox', Internet Movie Database, Inc <http://www.imdb.com/name/ $\mathrm{nm} 0000150 />$.

73 'Tobey Maguire’, Internet Movie Database, Inc <http://www.imdb.com/name/ nm0001497/>. 
74 For examples of those favoring the view that the boy actors were incapable of portraying adult roles in a theatrically convincing manner, see R.A. Foakes, 'John Marston's Fantastical Plays: Antonio and Mellida and Antonio's Revenge', Philological Quarterly 41 (1962), 229-39; Caputi, Marston, 112-3; and Michael Shapiro, 'Theatrical Perspectives of Children's Companies', Research Opportunities in Renaissance Drama 18 (1975), 13-18. For examples of those favoring the contrary view, see Ejner J. Jensen, 'The Style of the Boy Actors', Comparative Drama 2 (1968), 100-14; Richard Levin, 'The Proof of the Parody', Essays in Criticism 24 (1974), 312-7; Ann Blake, "'The Humour of Children": John Marston's Plays in the Private Theatres', Review of English Studies 38 (1987), 471-82; and Lucy Munro, Children of the Queen's Revels (Cambridge, 2005), 52-3. 